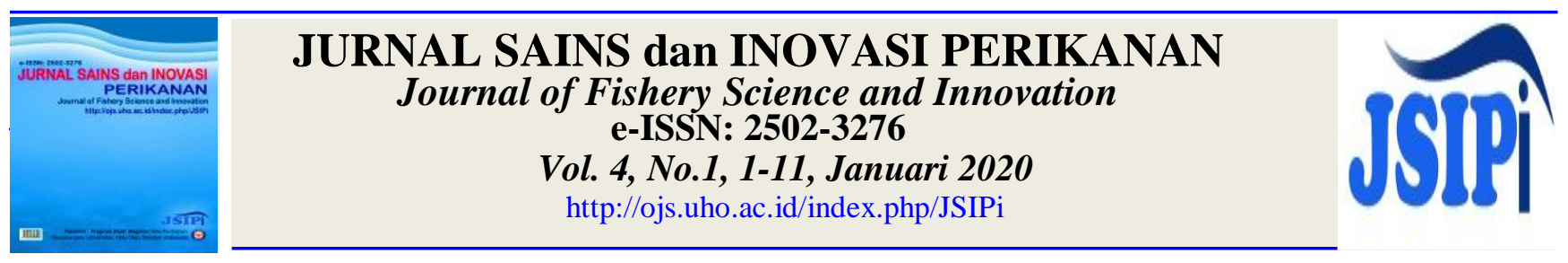

\title{
Komposisi By-catch Perikanan Lele Laut (Famili Plotosidae) di Perairan Teluk Kolono, Sulawesi Tenggara
}

\section{By-catch composition of fishery eel catfish (Plotosidae family) in Kolono Bay, Southeast Sulawesi}

\author{
Asriyana Asriyana $^{12) *}$, Halili Halili ${ }^{1}$, Nur Irawati $^{1{ }^{1}}$ \\ ${ }^{1)}$ Jurusan Manajemen Sumber daya Perairan, FPIK Universitas Halu Oleo, Kendari \\ ${ }^{2}$ Masyarakat Iktiologi Indonesia, Bogor \\ Corresponding author"): asriyana@uho.ac.id
}

\begin{abstract}
The by-catch on the gill net fisheries is the current global fisheries problems and issues. This study aimed to analyze by-catch composition of fishery eel catfish (Plotosidae) in Kolono Bay, Southeast Sulawesi. Sampling was done monthly from April to July 2019, with bottom experimental gillnets of 3/4,11/4,11/2,13/4, and 2 inches mesh sizes. The highest proportion of catches was found in by-catch $(62.72 \%)$ than the main target, the family Plotosidae (37.28\%). The by-catch includes 23 families consisting of two groups namely the useable by-catch $55.57 \%$ (19 families) and discarded by-catch 7.15\% (4 families). Out of these 23 families, 44 species belong to the Least Concern (LC) and 24 species Not Evaluated (NE) categories on the IUCN red list 2019. The results showed that the use of bottom gillnets in eel catfish fisheries has a low selectivity which is characterized by high diversity and low dominance of by-catch.
\end{abstract}

Keywords: by-catch, conservation status, Plotosidae, low selectivity

\begin{abstract}
ABSTRAK
Hasil tangkapan sampingan atau tangkapan ikan non target pada perikanan jaring insang merupakan permasalahan dan isu perikanan dunia saat ini. Tujuan penelitian ini adalah untuk menganalisis komposisi hasil tangkapan sampingan perikanan sembilang, Plotosidae di perairan Teluk Kolono. Penelitian dilaksanakan dari bulan April hingga Juli 2019 dengan menggunakan bottom experimental gillnets bermata jaring 3/4, 11/4, 1 1/2, 1 3/4, dan 2 inci. Jumlah ikan yang tertangkap sebanyak 605 individu yang meliputi 24 famili dan 68 jenis. Proporsi tertinggi hasil tangkapan ditemukan pada ikan hasil tangkapan sampingan $(62,72 \%)$ daripada ikan target utama, famili Plotosidae (37,28\%). Hasil tangkapan sampingan meliputi 23 famili terdiri dari dua kelompok yaitu hasil tangkapan sampingan yang digunakan (useable) sebesar 55,57\% (19 famili) dan hasil tangkapan sampingan yang tidak dimanfaatkan (discarded) sebesar 7,15\% (4 famili). Dari 23 famili tersebut, 44 jenis termasuk kategori beresiko rendah dan 24 jenis kategori belum dievaluasi dalam daftar merah IUCN 2019. Hasil penelitian menunjukkan bahwa penggunaan jaring insang dasar dalam perikanan lele laut mempunyai selektivitas rendah yang ditandai oleh tingginya keanekaragaman dan rendahnya dominansi hasil tangkapan sampingan..
\end{abstract}

Kata Kunci: Hasil tangkapan sampingan, Plotosidae, selektivitas rendah, status konservasi

DOI: http://dx.doi.org/10.33772/jsipi.v4i1.10201

\section{PENDAHULUAN}

Teluk Kolono merupakan perairan estuari yang telah lama dimanfaatkan oleh nelayan baik sebagai daerah budidaya maupun daerah penangkapan ikan. Beragam jenis alat tangkap yang beroperasi di perairan ini, salah satunya adalah jaring insang dasar.
Alat tangkap ini terbuat dari bahan jaring monofilamen, dengan bentuk empat persegi panjang, berukuran mata jaring yang sama, dan dioperasikan dengan sasaran penangkapan ikan demersal (Ayodhyoa, 1981; He, 2006; Emmanuel et al., 2010). Beberapa permasalahan pada kegiatan penangkapan ikan menggunakan gillnet yaitu rendahnya kualitas 
2 Asriyana, et al.

JURNAL SAINS dan INOVASI PERIKANAN / Journal of Fishery Science and Innovation

Vol. 4, No. 1, 1-11, Januari 2020

hasil tangkapan dan rendahnya selektivitas terhadap beberapa jenis ikan yang menjadi tujuan penangkapan (Arami \& Mustafa, 2010). Dalam pengoperasian jaring insang untuk menangkap ikan lele laut atau sembilang (Plotosidae), tidak hanya berpeluang menangkap ikan lele laut sebagai target utama, tetapi juga berbagai jenis ikan maupun non ikan yang masih juwana yang bukan merupakan target tangkapan (hasil tangkapan sampingan). Kondisi ini jika berlangsung terus menerus dikhawatirkan akan mengancam keanekaragaman dan produktivitas perairan Teluk Kolono.

Hasil tangkapan sampingan (by-catch) pada perikanan jaring insang merupakan masalah global. Tingginya jumlah hasil tangkapan sampingan merupakan salah satu penyebab stok ikan menurun sehingga memengaruhi keberlanjutan perikanan dunia (Hutchings \& Lamberth, 2002; Rainaldi et al., 2017). Umumnya ikan yang tertangkap sebagai hasil tangkapan sampingan mempunyai keterkaitan ekologi dengan ikan tangkapan utama (Watson \& Kerstetter, 2006). Informasi mengenai keanekaragaman hasil tangkapan sampingan jaring insang cukup banyak dengan berbagai target utama (Hutchings \& Lamberth, 2002; Rojo-Vázquez et al., 2007; Reeves et al., 2013; Moazzam \& Nawaz, 2014; Muhajirah et al., 2018; Mardhan et al., 2019) sementara informasi dengan target utama lele laut relatif terbatas. Hal ini yang melatarbelakangi sehingga diperlukan penelitian untuk menganalisis komposisi jenis hasil tangkapan sampingan pada perikanan lele laut di perairan Teluk Kolono. Informasi ini sangat penting sebagai dasar pengelolaan sumberdaya ikan lele laut di perairan Teluk Kolono.

\section{METODE PENELITIAN}

\section{Lokasi sampling}

Penelitian dilaksanakan dari bulan April sampai Juli 2019 di perairan Teluk Kolono, Sulawesi Tenggara. Posisi koordinat perairan Teluk Kolono

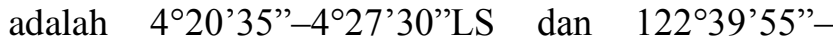
$122^{\circ} 47^{\prime} 49^{\prime \prime}$ BT (Gambar 1).

\section{Prosedur sampling}

Contoh ikan ditangkap dengan bottom experimental gillnets dari bahan nilon monofilamen dengan panjang $80 \mathrm{~m}$ untuk setiap ukuran mata jaring $\left(3 / 4,1 \frac{1}{4}, 11 \frac{1}{2}, 13 / 4\right.$, dan 2 inci). Pengambilan contoh ikan dilaksanakan setiap bulan selama tiga hari. Semua individu yang tertangkap diawetkan dalam larutan formalin 10\%, kemudian dianalisis lebih lanjut di Laboratorium Fakultas Perikanan dan Ilmu Kelautan, Universitas Haluoleo, Kendari.

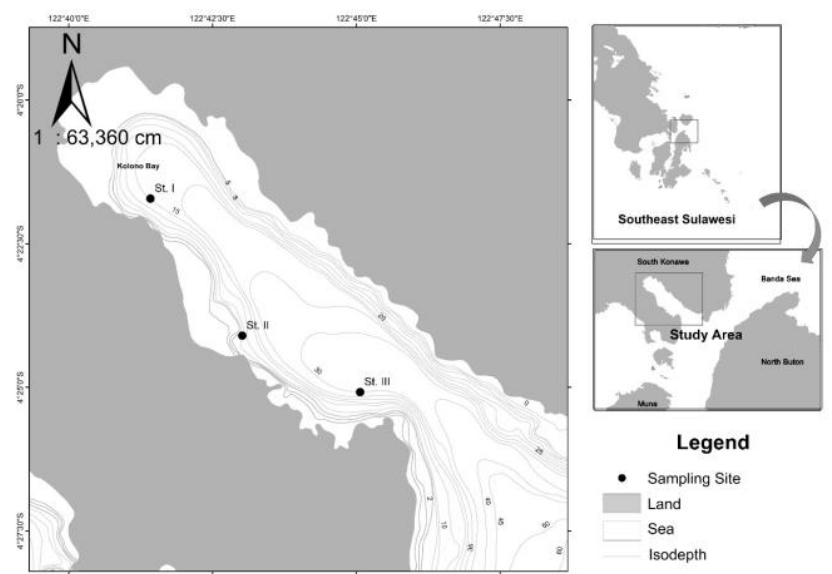

Gambar 1. Perairan Teluk Kolono, Sulawesi Tenggara

Di laboratorium, semua hasil tangkapan dipisahkan menurut jenis dan dihitung jumlah individu setiap jenisnya. Contoh ikan lele laut diidentifikasi menurut Carpenter \& Niem (1999) dan Froese \& Pauly (2019). Hasil tangkapan sampingan diidentifikasi menurut Allen (1999); Carpenter \& Niem (1999; 2001), Kuiter \& Tonozuka (2001), Peristiwady (2006), dan White et al. (2013). Setiap individu hasil tangkapan diukur yaitu panjang total dengan papan pengukur berketelitian $1 \mathrm{~mm}$ dan ditimbang bobotnya menggunakan timbangan dengan ketelitian 0,1 g. Hasil tangkapan kemudian dikelompokkan dalam tiga kategori yaitu target utama (main target), hasil tangkapan sampingan (bycatch) yang dapat dimanfaatkan (useable) dan hasil tangkapan sampingan yang dibuang (discarded).

Status konservasi semua hasil tangkapan yang diidentifikasi berdasarkan sembilan kategori menurut International Union for Conservation of Nature (IUCN) Red List of Threatened Species dalam website www.iucnredlist.org.

\section{Analisis Data}

Semua hasil tangkapan dihitung komposisi jenis dan ukuran, kelimpahan relatif, indeks keanekaragaman, dominansi hasil tangkapan, dan hasil tangkapan sampingan. Komposisi jenis dihitung menggunakan rumus Odum (1996) yaitu: 
Vol. 4, No. 1. 1-11, Januari 2020

$P_{i}=\frac{n i}{N} x 100 \%$

Keterangan : $P_{i}=$ Komposisi jenis (\%) ke-i, $n i=$ jumlah jenis ke-i, $N=$ jumlah total jenis.

Kelimpahan relatif dianalisis menurut formula :

$K_{r}=\frac{K_{i}}{K} \times 100 \%$

Keterangan : $K_{r}=$ Kelimpahan relatif, $K_{i}=$ jumlah individu jenis ke-i, $K=$ jumlah total individu semua jenis

Indeks keanekaragaman jenis dianalisis dengan indeks keanekaragaman Shannon-Wienner (Krebs, 1989) adalah :

$H^{\prime}=-\sum P_{i} \ln P$

Keterangan: H' = Indeks keanekaragaman ShannonWienner, $\mathrm{P}_{\mathrm{i}}=$ perbandingan antara jumlah individu jenis ke-i dan jumlah, $\mathrm{N}=$ total individu, dan $\mathrm{s}=$ jumlah jenis. Nilai indeks keanekaragaman dapat digunakan untuk menentukan tingkat selektivitas suatu jenis alat tangkap terhadap jenis yang ditangkap (Wiyono et al., 2006), dengan kategori: $\mathrm{H}^{\prime}>0,1=$ keanekaragaman tinggi, selektivitas alat tangkap rendah, $H^{\prime}=0=$ keanekaragaman rendah, selektivitas alat tangkap tinggi.

Dominansi jenis dihitung dengan indeks dominansi Simpson (Odum, 1996) yaitu:

$C=\sum_{i=1}^{n}\left(\frac{n i}{N}\right)^{2}$

Keterangan: $\mathrm{C}=$ Indeks dominansi Simpson, $\mathrm{Ni}=$ Jumlah individu jenis ke-i yang tertangkap, $\mathrm{N}=$ Jumlah total jenis yang tertangkap. Kriteria indeks dominansi yaitu : $\mathrm{C}<0,5=$ dominansi jenis hasil tangkapan rendah, suatu alat tangkap memiliki selektivitas yang rendah terhadap target penangkapan, $\mathrm{C}>0,5=$ dominansi jenis hasil tangkapan tinggi, suatu alat tangkap memiliki selektivitas yang tinggi terhadap target penangkapan.

Hasil tangkapan sampingan dianalisis menurut Akiyama (1997), yaitu :

Tingkat By - catch $=\frac{\sum \text { by }- \text { catch }}{\text { Total tangkapan }} \times 100 \%$

Tingkat Use able $=\frac{\sum \text { Use able }}{\text { Bycatch }} \times 100 \%$
Tingkat Discard $=\frac{\sum \text { Discarded }}{\text { By-catch }} \times 100 \%$

Keterangan: $\sum$ by-catch $=$ Jumlah individu hasil tangkapan sampingan (selain ikan target), $\sum$ useable = Jumlah hasil tangkapan yang masih bisa digunakan, $\sum$ discarded $=$ Jumlah hasil tangkapan yang dibuang kembali ke laut, Total tangkapan = Jumlah individu semua jenis ikan (jumlah total individu setiap pengambilan sampel).

\section{HASIL DAN PEMBAHASAN}

\section{Hasil}

Selama penelitian tertangkap 605 individu ikan yang meliputi 24 famili dan 68 jenis (Tabel 1). Kondisi tersebut menunjukkan bahwa sumber daya ikan di perairan Teluk Kolono beragam. Famili Plotosidae sebagai ikan target utama terdiri atas dua jenis yaitu $P$. canius dan $P$. lineatus. Famili tersebut mempunyai komposisi jenis sebesar 2,94\%, sedangkan famili lainnya mempunyai komposisi jenis yang bervariasi (Gambar 1). P. lineatus mempunyai jumlah individu terbesar (194 individu) daripada $P$. canius (30 individu) dengan sebaran ukuran yang bervariasi (Gambar 2).

Tabel 1. Hasil tangkapan jaring insang dasar selama penelitian di perairan Teluk Kolono

\begin{tabular}{clcc}
\hline No. & Family & $\begin{array}{c}\text { Jumlah } \\
\text { Individu } \\
\text { (ekor) }\end{array}$ & $\begin{array}{c}\text { Jumlah } \\
\text { Jenis }\end{array}$ \\
\hline 1 & Acanthuridae & 2 & 1 \\
2 & Ambassidae & 1 & 1 \\
3 & Apogonidae & 4 & 3 \\
4 & Atherinidae & 37 & 2 \\
5 & Gerreidae & 68 & 5 \\
6 & Labridae & 13 & 3 \\
7 & Leiognathidae & 6 & 3 \\
8 & Lutjanidae & 1 & 1 \\
9 & Lethrinidae & 4 & 2 \\
10 & Mugilidae & 10 & 3 \\
11 & Mullidae & 45 & 8 \\
12 & Monacanthidae & 1 & 1 \\
13 & Nemipteridae & 108 & 9 \\
14 & Pinguipedidae & 1 & 1 \\
15 & Platycephalidae & 5 & 1 \\
16 & Plotosidae & 224 & 2 \\
17 & Pomacentridae & 16 & 6 \\
18 & Scorphaenidae & 1 & 1 \\
19 & Serranidae & 17 & 5 \\
\hline
\end{tabular}


Tabel 1. (Lanjutan)

\begin{tabular}{clcc}
\hline No. & Family & $\begin{array}{c}\text { Jumlah } \\
\text { Individu } \\
\text { (ekor) }\end{array}$ & $\begin{array}{c}\text { Jumlah } \\
\text { Jenis }\end{array}$ \\
\hline 20 & Siganidae & 28 & 4 \\
21 & Sillaginidae & 2 & 1 \\
22 & Synanceiidae & 1 & 1 \\
23 & Synodontidae & 4 & 2 \\
24 & Teraponidae & 2 & 2 \\
\hline & Total & 605 & 68 \\
\hline
\end{tabular}

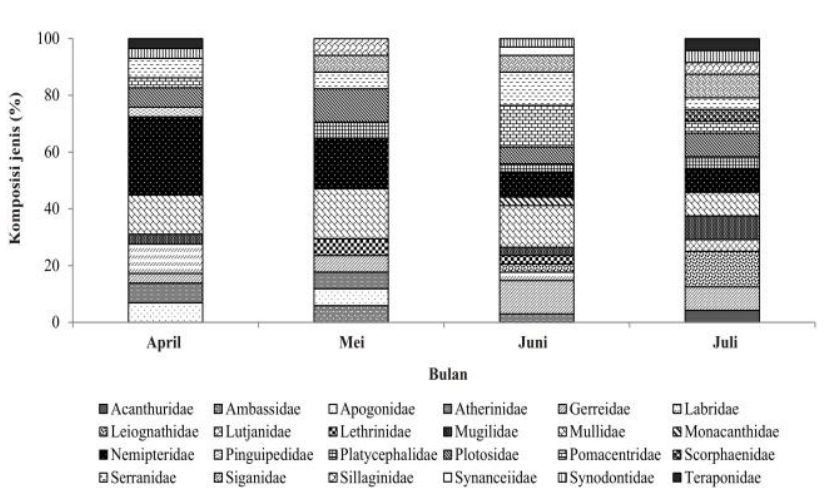

Gambar 1. Komposisi jenis hasil tangkapan jaring insang lele laut di perairan Teluk Kolono

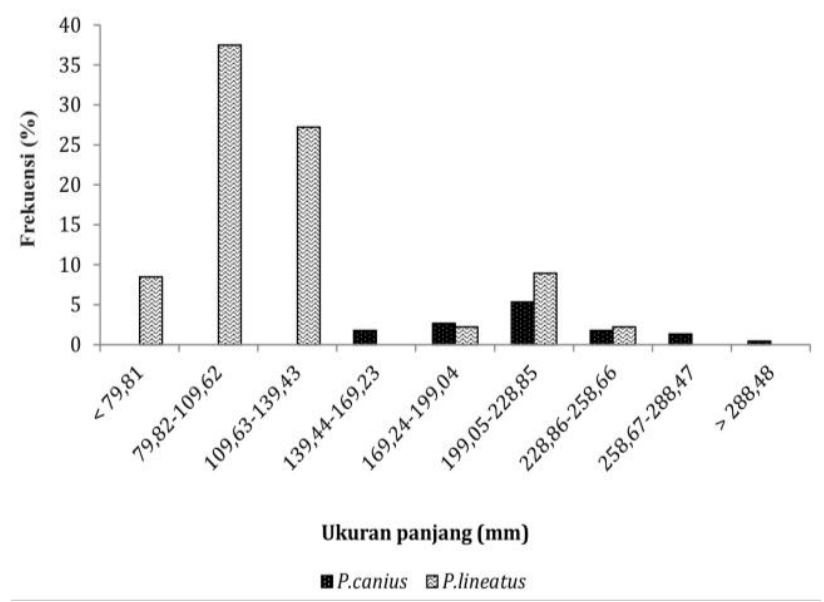

Gambar 2. Sebaran ukuran famili Plotosidae di perairan Teluk Kolono

Indeks keanekaragaman dan dominansi hasil tangkapan (Tabel 3) menunjukan indeks keanekaragaman tinggi dan indeks dominansi rendah yang menunjukkan bahwa alat tangkap yang digunakan lele lautmempunyai selektivitas rendah.
Kelimpahan relatif setiap famili yang tertangkap menunjukan kelimpahan relatif tertinggi ditemukan pada famili Plotosidae $(37,27 \%)$ dan terendah pada famili Ambassidae, Monacanthidae, Pinguipedidae, Scorphaenidae, dan Synanceiidae masing-masing sebesar 0,17\% (Gambar 3).

Tabel 3. Indeks keanekaragaman dan dominansi hasil tangkapan di perairan Teluk Kolono

\begin{tabular}{cccc}
\hline H' & Keterangan & C & Keterangan \\
\hline 2,7 & Tinggi & 0,1 & Rendah \\
1,6 & Tinggi & 0,4 & Rendah \\
2,9 & Tinggi & 0,1 & Rendah \\
1,7 & Tinggi & 0,4 & Rendah \\
\hline \multicolumn{2}{l}{ Keterangan $:$ H' $=$ keanekaragaman, $\mathrm{C}=$ dominansi }
\end{tabular}

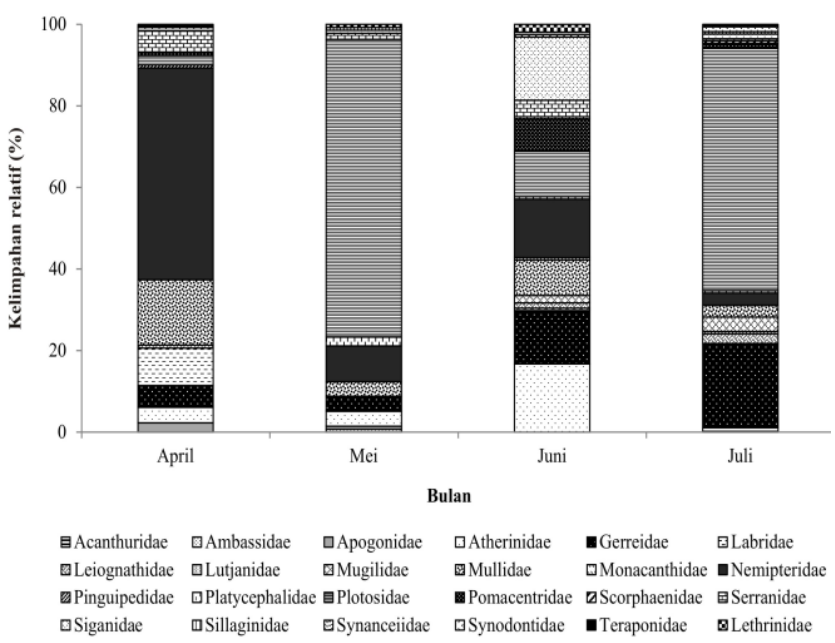

Gambar 3. Kelimpahan relatif hasil tangkapan di perairan Teluk Kolono

Dari 24 famili yang menjadi hasil tangkapan, proporsi antara target utama (ikan lele laut) dan hasil tangkapan sampingan tertera pada Gambar 4. Hasil tangkapan sampingan meliputi 23 famili yang meliputi dua kelompok yaitu hasil tangkapan yang digunakan (useable) sebesar 55,57\% (19 famili, Gambar 3) dan hasil tangkapan yang tidak dimanfaatkan (discard) yaitu dari famili Ambassidae, Apogonidae, Atherinidae, dan Pinguipedidae (7,15\%). 
Vol. 4, No. 1. 1-11, Januari 2020
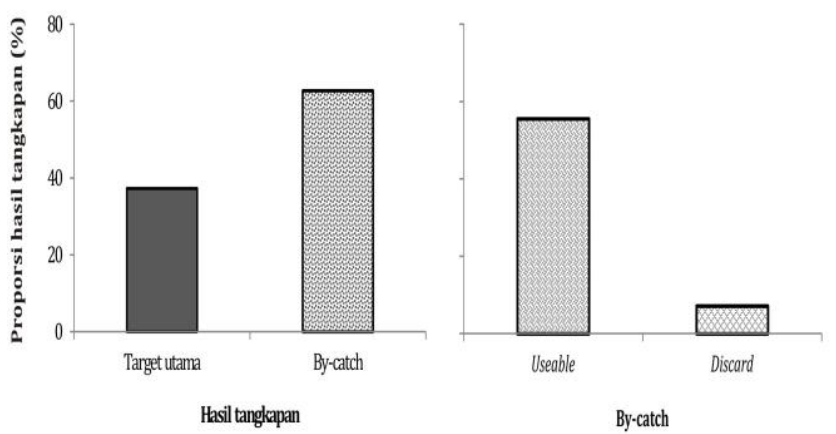

Gambar 4. Perbandingan hasil tangkapan utama, hasil tangkapan sampingan (by-catch), useable, dan discarded di perairan Teluk Kolono.
Berdasarkan status konservasi, ikan lele laut $P$. lineatus termasuk dalam kategori Least Concern-LC sedangkan $P$. canius dalam kategori Not EvaluatedNE. Sementara 66 jenis hasil tangkapan sampingan dalam perikanan lele laut dikategorikan ke dalam dua kelompok yaitu Not Evaluated-NE, belum dievaluasi (40,38\%) dan Least Concern-LC, beresiko rendah $(59,62 \%)$. Kategori yang lain dalam daftar merah IUCN tidak ditemukan (Tabel 2 dan Gambar 5).

Tabel 2. Status konservasi dari hasil tangkapan sampingan menurut Red List IUCN 2019

\begin{tabular}{|c|c|c|c|c|c|c|c|}
\hline \multirow{2}{*}{ No. } & \multirow{2}{*}{ Famili } & \multirow{2}{*}{ No. } & \multirow{2}{*}{ Jenis } & \multicolumn{4}{|c|}{ Secara Temporal } \\
\hline & & & & April & Mei & Juni & Juli \\
\hline 1 & Acanthuridae & 1 & Acanthurus maculiceps & & & & LC \\
\hline 2 & Ambassidae & 2 & Ambassis gymnocephalus & & $\mathrm{LC}$ & & \\
\hline \multirow[t]{3}{*}{3} & Apogonidae & 3 & Apogon melas & $\mathrm{NE}$ & & & \\
\hline & & 4 & Taeniamia fucata & & $\mathrm{LC}$ & & \\
\hline & & 5 & Fibramia amboinensis & $\mathrm{NE}$ & & & \\
\hline \multirow[t]{2}{*}{4} & Atherinidae & 6 & Atherinomorus lacunosus & LC & & $\mathrm{LC}$ & \\
\hline & & 7 & Atherinomorus duodecimalis & $\mathrm{NE}$ & $\mathrm{NE}$ & & \\
\hline \multirow[t]{5}{*}{5} & Gerreidae & 8 & Gerres oyena & $\mathrm{LC}$ & $\mathrm{LC}$ & $\mathrm{LC}$ & LC \\
\hline & & 9 & Gerres abreviatus & & & $\mathrm{NE}$ & \\
\hline & & 10 & Gerres acinaces & & & $\mathrm{LC}$ & \\
\hline & & 11 & Gerres filamentosus & & & $\mathrm{LC}$ & \\
\hline & & 12 & Gerres sp. & & & & $\mathrm{NE}$ \\
\hline \multirow[t]{3}{*}{6} & Labridae & 13 & Cheilinus chlorurus & $\mathrm{LC}$ & & & \\
\hline & & 14 & Halichoeres hortulanus & $\mathrm{LC}$ & & $\mathrm{LC}$ & \\
\hline & & 15 & Cherodon anchorage & $\mathrm{LC}$ & & & \\
\hline \multirow[t]{3}{*}{7} & Leiognathidae & 16 & Leiognathus equulus & & & $\mathrm{LC}$ & LC \\
\hline & & 17 & Leiognathus fasciatus & & & & LC \\
\hline & & 18 & Gazza achlamys & & & & LC \\
\hline 8 & Lutjanidae & 19 & Lutjanus fulviflamma & & & & LC \\
\hline \multirow[t]{2}{*}{9} & Lethrinidae & 20 & Lethrinus lentjan & & $\mathrm{LC}$ & & \\
\hline & & 21 & Lethrinus variegatus & & & $\mathrm{LC}$ & \\
\hline \multirow[t]{3}{*}{10} & Mugilidae & 22 & Planiliza subviridis & $\mathrm{LC}$ & & $\mathrm{LC}$ & LC \\
\hline & & 23 & Ellochelon vaigiensis & & & $\mathrm{NE}$ & $\mathrm{NE}$ \\
\hline & & 24 & Oedalechilus labiosus & & & & $\mathrm{NE}$ \\
\hline \multirow[t]{7}{*}{11} & Mullidae & 25 & Parupeneus multifasciatus & $\mathrm{LC}$ & & & \\
\hline & & 26 & Parupeneus forsskali & $\mathrm{NE}$ & & & \\
\hline & & 27 & Parupeneus heptacanthus & $\mathrm{LC}$ & & & \\
\hline & & 28 & Parupeneus barberinus & & $\mathrm{LC}$ & $\mathrm{LC}$ & \\
\hline & & 29 & Upeneus tragula & $\mathrm{LC}$ & $\mathrm{LC}$ & $\mathrm{LC}$ & LC \\
\hline & & 30 & Upeneus sulphureus & & $\mathrm{LC}$ & $\mathrm{LC}$ & \\
\hline & & 31 & Upeneus mollucensis & & & $\mathrm{NE}$ & $\mathrm{NE}$ \\
\hline
\end{tabular}


6 Asriyana, et al.

JURNAL SAINS dan INOVASI PERIKANAN / Journal of Fishery Science and Innovation

Vol. 4, No. 1, 1-11, Januari 2020

Tabel 2. (Lanjutan)

\begin{tabular}{|c|c|c|c|c|c|c|c|}
\hline \multirow{2}{*}{ No. } & \multirow{2}{*}{ Famili } & \multirow{2}{*}{ No. } & \multirow{2}{*}{ Jenis } & \multicolumn{4}{|c|}{ Secara Temporal } \\
\hline & & & & April & Mei & Juni & Juli \\
\hline & & 32 & Upeneus sundaicus & & & $\mathrm{LC}$ & \\
\hline 12 & Monacanthidae & 33 & Monacanthus chinensis & & & $\mathrm{LC}$ & \\
\hline \multirow[t]{9}{*}{13} & Nemipteridae & 34 & Nemipterus aurora & $\mathrm{NE}$ & & & \\
\hline & & 35 & Nemipterus hexodon & LC & $\mathrm{LC}$ & & \\
\hline & & 36 & Nemipterus nematopus & & & & \\
\hline & & 37 & Scolopsis ciliata & LC & $\mathrm{LC}$ & $\mathrm{LC}$ & LC \\
\hline & & 38 & Scolopsis affinis & LC & & & \\
\hline & & 39 & Scolopsis monogramma & LC & & & \\
\hline & & 40 & Scolopsis margaritifer & & $\mathrm{LC}$ & & \\
\hline & & 41 & Pentapodus trivittatus & LC & & $\mathrm{LC}$ & \\
\hline & & 42 & Pentapodus bifasciatus & $\mathrm{NE}$ & & $\mathrm{NE}$ & $\mathrm{NE}$ \\
\hline 14 & Pinguipedidae & 43 & Parapercis xanthozona & LC & & & \\
\hline 15 & Platycephalidae & 44 & Grammoplites scaber & & $\mathrm{NE}$ & $\mathrm{NE}$ & $\mathrm{NE}$ \\
\hline \multirow[t]{2}{*}{16} & Plotosidae & 45 & Plotosus lineatus & LC & $\mathrm{LC}$ & $\mathrm{LC}$ & $\mathrm{LC}$ \\
\hline & & 46 & Plotosus canius & $\mathrm{NE}$ & $\mathrm{NE}$ & $\mathrm{NE}$ & $\mathrm{NE}$ \\
\hline \multirow[t]{6}{*}{17} & Pomacentridae & 47 & Pomacentrus reidi & $\mathrm{NE}$ & & & $\mathrm{NE}$ \\
\hline & & 48 & Amblypomacentrus breviceps & & & $\mathrm{LC}$ & \\
\hline & & 49 & Pomacentrus fasciatus & & & $\mathrm{NE}$ & \\
\hline & & 50 & Dischistodus pseudochrysopoecilus & & $\mathrm{NE}$ & & \\
\hline & & 51 & Dischistodus perspicillatus & & & $\mathrm{NE}$ & \\
\hline & & 52 & Dischistodus chrysopoecilus & & & $\mathrm{NE}$ & \\
\hline 18 & Scorphaenidae & 53 & Scorpaenopsis oxycephala & & & & $\mathrm{LC}$ \\
\hline \multirow[t]{5}{*}{19} & Serranidae & 54 & Centrogenys vaigiensis & $\mathrm{NE}$ & $\mathrm{NE}$ & $\mathrm{NE}$ & $\mathrm{NE}$ \\
\hline & & 55 & Cephalopholis boenack & $\mathrm{NE}$ & & & \\
\hline & & 56 & Cromileptis altivelis & & & $\mathrm{NE}$ & \\
\hline & & 57 & Epinephelus corallicola & & & $\mathrm{LC}$ & \\
\hline & & 58 & Cephalopholis microprion & & & $\mathrm{LC}$ & \\
\hline \multirow[t]{4}{*}{20} & Siganidae & 59 & Siganus virgatus & & & & LC \\
\hline & & 60 & Siganus canaliculatus & & & $\mathrm{LC}$ & \\
\hline & & 61 & Siganus guttatus & & & $\mathrm{LC}$ & \\
\hline & & 62 & Siganus doliatus & & & & $\mathrm{LC}$ \\
\hline 21 & Sillaginidae & 63 & Sillago sihama & & $\mathrm{LC}$ & & LC \\
\hline 22 & Synanceiidae & 64 & Synanceja horrida & & & $\mathrm{NE}$ & \\
\hline \multirow[t]{2}{*}{23} & Synodontidae & 65 & Saurida tumbil & LC & & & $\mathrm{LC}$ \\
\hline & & 66 & Saurida nebulosa & & & $\mathrm{LC}$ & \\
\hline \multirow[t]{5}{*}{24} & Teraponidae & 67 & Pelates quadrilineatus & LC & & & \\
\hline & & 68 & Therapon jarbua & & & & - \\
\hline & & & Not Evaluated (NE) & 10 & 4 & 13 & 10 \\
\hline & & & Least Concern (LC) & 18 & 12 & 22 & 15 \\
\hline & & & Total Jenis & 28 & 16 & 35 & 25 \\
\hline
\end{tabular}




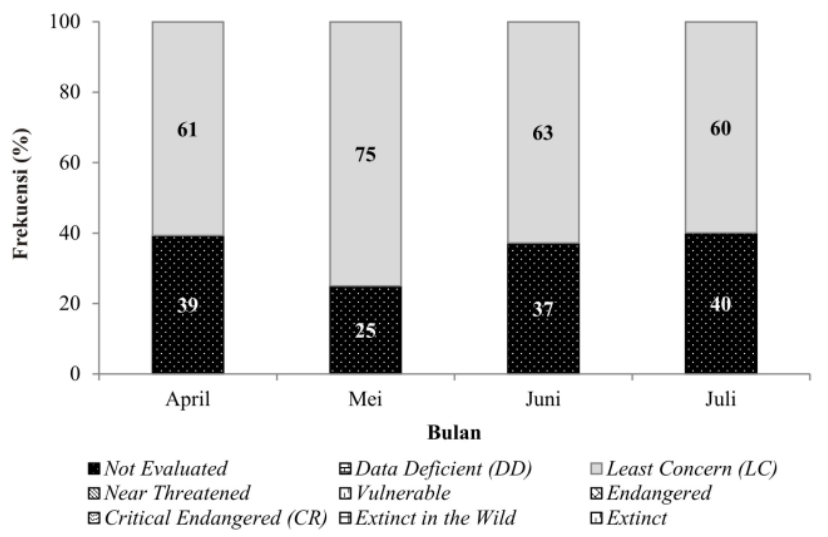

Gambar 5. Status konservasi hasil tangkapan di perairan Teluk Kolono

\section{Pembahasan}

Sumber daya ikan di perairan Teluk Kolono cukup bervariasi. Secara temporal, famili Nemipteridae mempunyai komposisi jenis tertinggi saat bulan April (27,59\%), bulan Mei famili Nemipteridae dan Mullidae (17,65\%), bulan Juni famili Mullidae dan Pomacentridae $(14,72 \%)$, sementara bulan Juli famili Leiognathidae $(12,50 \%)$. Famili ikan dengan komposisi jenis tertinggi merupakan bagian dari hasil tangkapan sampingan dari perikanan lele laut di Teluk Kolono. Variasi komposisi jenis di Teluk Kolono berhubungan dengan siklus hidup dari famili ikan tersebut. Teluk Kolono merupakan perairan dengan potensi sumber daya mangrove yang cukup besar, lamun, dan karang (Bappeda Konawe Selatan, 2011). Ikan-ikan yang ditemukan di Teluk Kolono diduga merupakan ikanikan yang menghuni ekosistem perbatasan yang saat air pasang masuk ke dalam teluk untuk mencari makanan dan daerah perlindungan dan saat air surut kembali ke habitat aslinya. Kelompok ikan demersal yang sering ditemukan di kawasan mangrove diantaranya adalah famili Lutjanidae, Mullidae, Mugillidae, Serranidae, Siganidae, Terraponidae, Leiognathidae, Nemipteridae (Genisa, 2006; Asriyana et al., 2009; Findra et al., 2016). Ekosistem mangrove merupakan habitat penting bagi sebagian besar biota laut (Beck et al., 2001; Lugendo et al., 2006; Jin et al., 2007; Nanjo et al., 2014; Edworthy \& Strydom, 2016) khususnya saat stadia juvenil dan umumnya merupakan ikan-ikan bernilai ekonomis (Asriyana et al., 2009; Kimirei et al., 2011; Nanjo et al., 2014; Asriyana et al., 2018).
Pemanfaatan habitat Teluk Kolono oleh beberapa famili ikan tergantung pada orientasi dari jenis ikan. Perpindahan ontogenetik habitat ikan berkaitan dengan sumberdaya makanan (Asriyana \& Sjafei, 2012), perlindungan dari predator, dan untuk proses reproduksi. Pemangsaan dapat mengurangi tingkat kemampuan suatu individu dalam mencari makan dan berimplikasi terhadap pertumbuhan. Kawasan ekosistem mangrove menyediakan tempat berlindung yang baik dari predator bagi ikan-ikan muda sehingga daerah ini digunakan sebagai daerah asuhan dan pembesaran seperti yang dikemukakan oleh Wang et al. (2009) di Teluk Dongzhaigang, China; Nanjo et al. (2014); dan Asriyana et al. (2018) di Teluk Kendari, Indonesia.

Famili Plotosidae sebagai target utama penangkapan memiliki ukuran yang bervariasi (Gambar 2). Kelompok ukuran < 139,4 mm terlihat lebih dominan daripada kelompok lainnya. $P$. lineatus didominasi oleh ukuran $<139,4 \mathrm{~mm}$ dan umumnya merupakan ikan stadia juvenil, sementara ukuran 169,24-258,6 mm merupakan ukuran ikan dewasa dilihat dari tingkat kematangan gonadnya (data belum dipublikasikan). Sebaliknya $P$. canius didominasi oleh kelompok ukuran 199,05-228,85 mm daripada kelompok lainnya dan merupakan kelompok ikan dewasa.

Berdasarkan hasil perhitungan indeks keanekaragaman dan dominansi, diketahui bahwa jaring insang dasar sebagai alat tangkap ikan famili Plotosidae mempunyai selektivitas yang rendah yang ditunjukan oleh tingginya keanekaragaman dan rendahnya dominansi hasil tangkapan. Hal ini dapat dipahami karena perairan Indonesia merupakan perairan tropis yang dicirikan oleh tingginya keragaman jenis (multi spesies) dan diikuti oleh rendahnya kelimpahan individu jenis.

Sebagai target utama tangkapan, famili Plotosidae mempunyai kelimpahan individu tertinggi daripada famili lainnya (Gambar 3). Walaupun demikian, proporsi hasil tangkapannya lebih rendah daripada hasil tangkapan sampingan (Gambar 4). Tingginya by-catch tersebut menunjukkan bahwa penggunaan alat jaring insang dasar kurang efektif sebagai alat tangkap ikan lele laut. Kurang selektifnya alat tangkap merupakan faktor utama yang memberikan kontribusi yang besar terhadap jumlah hasil tangkapan sampingan sehingga 
8 Asriyana, et al.

JURNAL SAINS dan INOVASI PERIKANAN / Journal of Fishery Science and Innovation

Vol. 4, No. 1, 1-11, Januari 2020

penggunaan ukuran mata jaring dan durasi waktu alat tangkap dioperasikan di perairan perlu diatur (Borges et al., 2001). Kondisi tersebut tidak hanya terjadi pada Plotosidae sebagai target utama, namun juga terjadi pada beberapa famili lainnya yang menggunakan jaring insang sebagai alat tangkap (Kyle, 1999; Hutchings \& Lamberth, 2002; RojoVázquez et al., 2007; Moazzam \& Nawaz, 2014; Salim \& Kelen, 2017; Muhajirah et al., 2018). Hasil tangkapan sampingan tersebut tidak dapat dihindari sehingga dapat mengancam keberlanjutan sumber daya perairan, tidak hanya pada jenis ikan, namun berdampak pada biota lainnya seperti crustacea (Kaiser et al., 1996; Brothers, 2001; Benavides, 2018), penyu (Gilman et al., 2009; Benavides, 2018), dan mamalia laut (Amir et al., 2002; Dagys et al., 2009; Reeves et al., 2013; Benavides, 2018).

Dari $62,72 \%$ hasil tangkapan sampingan, $55,57 \%$ merupakan hasil tangkapan yang digunakan (useable) sebanyak 19 famili dan $7,15 \%$ hasil tangkapan yang tidak dimanfaatkan (discard) sebanyak 4 famili (Gambar 3). Hasil tangkapan sampingan yang dimanfaatkan dapat dilihat dari jenis maupun ukuran. Ikan-ikan yang bernilai ekonomis dapat dipasarkan, sedangkan yang berukuran kecil seperti famili Serranidae dan Lutjanidae dapat dipelihara dalam keramba jaring apung (KJA) hingga berukuran siap untuk dipasarkan. Sementara hasil tangkapan yang tidak dimanfaatkan, selain kurang ekonomis, merupakan ikan juvenil, juga berada dalam kondisi sudah mati sehingga tidak memungkinkan untuk dikembalikan ke dalam perairan. Kondisi demikian jika berlangsung terus menerus dikhawatirkan akan mengancam kelestarian sumber daya perairan.

Ikan-ikan yang masuk dalam kategori useable dan discarded merupakan bagian dari sistem trofik dalam jejaring makanan. Penangkapan terhadap jenis target dan turut tertangkapnya ikan non target (bycatch: useable dan discarded) menyebabkan jenis lainnya yang memanfaatkan sumber daya yang sama (habitat dan makanan) menjadi dominan. Demikian pula predator dari jenis tersebut akan berkurang jumlahnya karena ketersediaan jenis mangsa berkurang akibat penangkapan. Beberapa jenis ikan mangsa yang memanfaatkan sumber daya makanan yang sama dengan jenis target dan non target mempunyai peluang yang besar dalam kompetisi baik itu kompetisi terhadap makanan maupun habitat karena sumber daya tersebut semakin berkurang ketersediaanya. Ikan yang dapat memanfaatkan sumber daya dengan baik dan lebih superior mempunyai peluang lebih besar untuk berkembang di perairan sehingga memungkinkan terjadinya dominansi dari jenis ikan tertentu (Jennings et al., 2003). Dominansi jenis tersebut akan menekan populasi ikan lainnya dan merubah komposisi ikanikan yang ada sehingga keragaman komunitas berkurang. Oleh karena itu eksploitasi terhadap jenis target dan non target dapat menyebabkan populasi ikan lainnya akan musnah sebagai hasil jika interaksi ekologi diantara mangsa diabaikan. Keadaan ini telah dilaporkan oleh Jennings \& Polunin (1997); Jennings et al. (2003); Jennings \& Blanchard (2004) mengenai dampak berkurangnya predator akibat penangkapan terhadap biomassa dan keragaman ikan non target.

Status konservarsi merupakan kondisi resmi dari kelompok organisme (seperti spesies) dinyatakan berada pada kondisi antara masih bertahan hidup (extant) dan punah (extinct) terhadap flora dan fauna yang terdapat di suatu wilayah, meliputi 9 kategori yaitu Not Evaluated, Data Deficient (DD), Least Concern (LC), Near Threatened, Vulnerable, Endangered, Critical Endangered (CR), Extinct in the Wild, Extinct (IUCN, 2019). Status konservasi ikan hasil tangkapan jaring insang dasar di Teluk Kolono sebagaimana yang terdaftar dalam red list IUCN, berada dalam dua kategori (Gambar 5). Jenis ikan hasil tangkapan yang termasuk kategori beresiko rendah tertinggi ditemukan saat bulan Juni (22 jenis) sementara terendah ditemukan saat bulan Mei (12 jenis). Kategori beresiko rendah (LC) IUCN diberikan untuk spesies yang telah dievaluasi namun tidak termasuk ke dalam 8 kategori lainnya (Tabel 2). Sementara jenis ikan kategori belum dievaluasi tertinggi ditemukan saat bulan Juni (13 jenis) dan terendah saat bulan Mei (4 jenis). Kategori belum dievaluasi merupakan kondisi takson yang belum dilakukan evaluasi berdasarkan terpenuhinya kriteriakriteria status konservasi yang berlaku menurut pedoman IUCN Red List seperti habitat, tingkat stress, tingkat ancaman, pelaksanan konservasi yang tersedia, tingkat kebutuhan konservarsi, dan tingkat kebutuhan untuk dilakukan penelitian lebih lanjut (IUCN, 2019). Kategori dalam status konservasi tersebut dapat saja berubah seiring waktu dengan meningkatnya intensitas penangkapan (ikan target dan non target) tanpa ada tindakan pengelolaan terhadap sumber daya ikan baik oleh pemerintah maupun instansi terkait. Perubahan status konservasi 
suatu sumber daya telah dilaporkan pada ikan tuna bluefin Pasifik (Thunnus orientalis), sebelumnya dikelompokkan sebagai least concern, namun berubah menjadi vulnerable; ikan takifugu (Cina pufferfish), belut Amerika (Anguilla rostrata), dan belut jepang (Anguilla japonica) (IUCN 2019).

\section{KESIMPULAN}

Kelimpahan famili Plotosidae sebagai ikan target utama cukup tinggi di perairan Teluk Kolono namun proporsi hasil tangkapan sampingan lebih besar yang berasal dari 23 famili dan 66 jenis ikan. Penggunaan jaring insang dasar dalam perikanan lele laut kurang efektif karena hasil tangkapan sampingan cukup tinggi daripada hasil tangkapan utama. Kondisi ini perlu menjadi perhatian dari instansi terkait dalam upaya pengelolaan sumber daya ikan di perairan Teluk Kolono agar berkelanjutan.

Ucapan Terima Kasih : Penulis mengucapkan terima kasih kepada Kementerian Riset, Teknologi, dan Pendidikan Tinggi atas bantuan dana penelitian dalam skim hibah Kompetitif Nasional "Penelitian Dasar" Tahun 2019 (No. Kontrak 171/SP2H/LT/ DRPM/2019 dan No. 511F/UN29.20/PPM/2019). Penulis juga mengucapkan terima kasih kepada alumni (Risko Arsyad, S.Pi., Dayuman, S.Pi., Anggaril Akbar, S.Pi., La Asrin, S.Pi.) dan mahasiswa FPIK (Zamrun Rabu, Andika Reza Pratama, dan Rines Andani) atas bantuannya dalam pengumpulan data di lapangan; Fakultas Perikanan dan Ilmu Kelautan Universitas Halu Oleo atas seluruh dukungan fasilitas dalam penyelesaian penelitian ini.

\section{DAFTAR PUSTAKA}

Akiyama S. 1997. Discarded catch of set-net fisheries in Tateyama Bay. J. Tokyo Univ. Fish. 84: 53-64.

Allen G. 1999. A field guide for anglers and divers: Marine fishes of South East Asia. Singapore: Periplus edition (HK) Ltd. 292 P.

Amir OA, Berggren P, Jiddawi NS. 2002. The incidental catch of dolphins in gillnet fisheries in zanzibar, tanzania. J. Mar. Sci. 1(2): 155-162.

Arami H, Mustafa A. 2010. Analisis selektivitas gillnet yang dioperasikan di Perairan Lentea,
Kecamatan Kaledupa Selatan Kabupaten Wakatobi. Warta Iptek 18(1): 38-43.

Asriyana, Rahardjo MF, Sukimin S, Lumban Batu D TF, Kartamihardja ES. 2009. Keanekaragaman ikan di Teluk Kendari. Jurnal Iktiologi Indonesia 9(2): 97-112.

Asriyana, Irawati N, Indrayani. 2018. Trophic ecology of twoblotch ponyfish Nuchequula blochii in Kendari Bay, Southeast Sulawesi, Indonesia. AACL Bioflux 11(1): 66-82.

Ayodhyoa. 1981. Metode Penangkapan Ikan. Yayasan Dewi Sri, Bogor. 38-43.

Bappeda Konawe Selatan. 2011. Master Plan Pengembangan Minapolitan. [Laporan Akhir]. Badan Perencanaan dan Pembangunan Daerah Konawe Selatan. Kerjasama Bappeda Konawe Selatan dan Lembaga Penelitian Universitas Halu Oleo.

Beck MW, Heck KL, Able KW, Childers DL, Eggleston DB, Gillanders BM, Halpern B, Hays CG, Hoshino K, Minello TJ, Orth RJ, Sheridan PF, Weinstein MP. 2001 The identification, conservation, and management of estuarine and marine nurseries for fish and invertebrates: a better understanding of the habitats that serve as nurseries for marine species and the factors that create sitespecific variability in nursery quality will improve conservation and management of these areas. Bioscience 51: 633-641.

Benavides J. 2018. The Negative Impacts of Gillnet Fishing on Marine Ecosystems: A Scientific Review. Universidad Andres Bello, Chile.

Borges TC, Erzini K, Bentes L, Costa ME, Goncalves JMS, Lino PG, Pais C, Ribeiro J. 2001. By-catch and discarding practices in vive Algarve (southern Portugal) meÂ tiers. J. Appl. Ichthyol. 17: 104-114.

Brothers G. 2001. Reducing snow crab by-catch in turbot gillnets. [Project Summary]. Conservation Technology Program Planning and Coordination Fisheries Management Sector. Canada.

Carpenter KE, Niem VH (eds). 1999. FAO species identification guide for fishery purposes. The living marine resources of the Western Central Pacific. Volume 3. Batoid fishes, Chimaeras and bony fish part 1 (Elopidae to Linophrynidae). Rome, FAO. pp. 1880-1883. 
10 Asriyana, et al.

JURNAL SAINS dan INOVASI PERIKANAN / Journal of Fishery Science and Innovation

Vol. 4, No. 1, 1-11, Januari 2020

Dagys M, Ložys L, Žydelis R, Stīpniece A, Minde A, Vetemaa M. 2009. Action C1 - Assessing and reducing impact of fishery by-catch on species of community interest. Final Report. LIFE Nature project "Marine Protected Areas in the Eastern Baltic Sea" Reference number: LIFE 05 NAT/LV/000100.

Edworthy C, Strydom N. 2016 Habitat partitioning by juvenile fishes in a temperate estuarine nursery, South Africa. Scientia Marina 80(2): 151-161.

Emmanuel, Eniola B, Chukwu, Obinna L. 2010. Evaluating the selective peformances of gill net used in tropical low brackish Lagoon South-Western, Nigeria. Journal of American Science 6(1): 49-52.

Findra MN, Hasrun LA, Adharani N. 2016. Perpindahan ontogenetik habitat ikan di perairan ekosistem hutan mangrove. Media Konservasi 21(3): 304-309.

Froese R, Pauly D (Editors). 2019. FishBase. World Wide Web electronic publication. www.fishbase.org, version (08/2019).

Gillman E, Gearhart J, Price B, Eckert S, Milliken H, Wang J, Swimmer Y, Shiode D, Abe O, Peckham SH, Chaloupka M, Hall M, Mangel J, Alfaro-Shigueto J, Dalzell P, Ishizaki A. 2009. Mitigating sea turtle by-catch in coastal passive net fisheries. Fish and Fisheries. $\quad$ DOI: $\quad 10.1111 /$ j.14672979.2009.00342.x.

He P. 2006. Gillnets: Gear Design, Fishing Performanceand Conservation Challenges. [Paper]. University of New Hampshire Institute for the Study of Earth, Oceans and Space and New Hampshire Sea Grant.

Hutchings K, Lamberth SJ. 2002. By-catch in the gillnet and beach-seine fisheries in the Western Cape, South Africa, with implications for management. S. Afr. J. mar. Sci. 24: 227-241.

International Union for Conservation of Nature (IUCN). 2019. Red List of Threatened Species.

Jennings S, Blanchard J. 2004. Fish abundance with no fishing: Predictions based on macroecological theory. Journal of Animal Ecology 73: 632-642.
Jennings S, Kaiser MJ, Reynolds JD. 2003. Marine Fisheries Ecology. New York: Blackwell Publishing.

Jennings S, Polunin NVC. 1997. Impacts of predator depletion by fishing on the biomass and diversity of non-target fish communities. Coral Reefs 16: 71-82.

Jin B, Fu C, Zhong J, Li B, Chen J, Wu J. 2007. Fish utilization of a salt marsh intertidal creek in the Yangtze River estuary, China. Estuarine, Coastal and Shelf Science 73(3-4): 844-852.

Kaiser MJ, Bullimore B, Newman P, Lock K, Gilbert S. 1996. Catches in 'ghost fishing' set nets. Marine Ecology Progress Serries. 145: 11-16.

Kuiter RH, Tonozuka T. 2001. Pictorial Guide to Indonesia Reef Fishes. Part 1 Muraenidae to Lutjanidae. Zoonetic. Australia. 302p.

Kyle R. 1999. Gillnetting in nature reserves: a case study from the Kosi Lakes, South Africa. Biol. Conserv. 88: 183-192.

Lugendo BR, Nagelkerken I, Mgaya YD. 2006. The importance of mangroves, mud and sand flats, and seagrass beds as feeding areas for juvenile fishes in Chwaka Bay, Zanzibar: Gut content and stable isotope analyses. Journal of Fish Biology 69: 1639-1661.

Mardhan NT, La Sara, Asriyana. 2019. Analisis hasil tangkapan rajungan (Portunus pelagicus) sebagai target utama dan komposisi by-catch alat tangkap gillnet di perairan Pantai Purirano, Sulawesi Tenggara. Jurnal Biologi Tropis, 19 (2) : 205 - 213.

Moazzam M, Nawaz R. 2014. By-catch of tuna gillnet fisheries of Pakistan: A serious threat to non-target, endangered and threatened species. J. Mar. Biol. Ass. India 56(1): 85-90.

Muhajirah E, La Sara, Asriyana. 2018. Keanekaragaman dan hasil tangkapan sampingan Jaring Insang di perairan Lalowaru Kabupaten Konawe Selatan. Jurnal Manajemen Sumber Daya Perairan 3(1): 4354.

Nanjo K, Kohno H, Nakamura Y. Differences in fish assemblage structure between vegetated and unvegetated microhabitats in relation to food abundance patterns in a mangrove creek. Fisheries Science 80: 21-41.

Odum EP. 1996. Dasar-Dasar Ekologi (Terjemahan Samingan T) Edisi Ketiga, Cetakan Ketiga. 
Gadjah Mada University Press. Yogyakarta. 697 hal.

Peristiwady T. 2006. Ikan-ikan Laut Ekonomis Penting di Indonesia; Petunjuk identifikasi. LIPI Press. Jakarta. 270 p.

Rainaldi B, Zamdial, Hartono D. 2006. Komposisi hasil tangkapan sampingan (by-catch) perikanan Pukat udang skala kecil di perairan laut Pasar Bantal Kabupaten Mukomuko. Jurnal Enggano 2(1): 101-114.

Reeves RR, McClellan K, Werner TB. 2013. Marine mammal by-catch in gillnet and other entangling net fisheries, 1990 to 2011. Endangered Species Research 20: 71-97

Rojo-Vázquez JA, Quiñonez-Velázquez C, Echavarria-Heras HA, Lucano-Ramírez G, Godínez-Domínguez E, Ruiz-Ramírez S, Galván-Piña VH, Sosa-Nishizaki O. 2007. The fish species composition and variation of catch from the small-scale gillnet fishery before, during and after the 1997-1998 ENSO event, central Mexican Pacific. Rev.
Biol. Trop. (Int. J. Trop. Biol.) 56 (1): 133152.

Salim G, Kelen PB. 2017. Analisis identifikasi komposisi hasil tangkapan menggunakan alat tangkap jaring insang hanyut (drift gill net) di sekitar Pulau Bunyu, Kalimantan Utara. Jurnal Harpodon Borneo 10(1): 13-22.

Wang M, Huang Z Shi F, Wang W. 2009. Are vegetated areas mangroves attractive to juvenil and small fish? The case of Dongzhaigang Bay, Hainan Island, China. Estuarine, Coastal and Shelf Science 85 : 208-217.

Watson JW, Kerstetter DW. 2006. Pelagic longline fishing gear: a brief history and review of research efforts to improve selectivity. Marine Technology Society Journal 40(3): 611.

White WT, Last PR, Dharmadi, Faizah R, Chodorojah U, Prisantoso BI, Pogonoski JJ, Puckridge M, Blader SJM. 2013. Jenis-Jenis Ikan di Indonesia. Canberra ACT. Australia. $155 \mathrm{hlm}$. 